\title{
Evaluation of different methodologies for the determination of phenolic compounds in tropical fruits
}

\section{Avaliação de diferentes metodologias para determinação de compostos fenólicos em frutas tropicais}

\author{
Karina Carvalho Guimarães ${ }^{1 *}$ (D), Derlyene Lucas Salgado1, \\ Elisângela Elena Nunes Carvalho ${ }^{1}$
}

${ }^{1}$ Universidade Federal de Lavras (UFLA), Departamento de Ciências dos Alimentos, Lavras/MG - Brasi

*Corresponding Author: Karina Carvalho Guimarães, Universidade Federal de Lavras (UFLA), Departamento de Ciências dos Alimentos, Campus Universitário, Caixa Postal: 3037, CEP: 37200-000,

Lavras/MG - Brasil, e-mail: kcg.itu@gmail.com

Cite as: Guimarães, K. C., Salgado, D. L., \& Carvalho, E. E. N. (2020). Evaluation of different methodologies for the determination of phenolic compounds in tropical fruits. Brazilian Journal of Food Technology, 23, e2019015.

https://doi.org/10.1590/1981-6723.01519

\begin{abstract}
Phenolic compounds are natural antioxidants and can be found with abundance in fruits and vegetables. One of the first methods created for analyzing phenolic compounds was the Folin-Denis method; and hereafter, the Folin Ciocalteu method was developed and recently, one of the most recent method is the Fast Blue. Due to the importance of these compounds in food, this work aimed to determine the total phenolic compounds in three fruits, such as: Passion Fruit, "Palmer" mango and "Pera" orange. In addition, these fruits were analyzed through three different determination methods. Furthermore, the content of vitamin C, soluble solids, titratable acidity and $\mathrm{pH}$ of these fruits were evaluated. Based on the results, it was verified that there was no difference among the values of vitamin $C$, soluble solids and TA in relation to those found in the literature. When comparing the three methods (Fast Blue BB, Folin-Ciocalteu Reagent and Folin-Denis Reagent), the results showed a difference in the phenolic compounds that may be related to the distinct reagents used in each method and its different action.
\end{abstract}

Keywords: Fast Blue BB; Folin-Denis; Folin-Ciocalteu; Quantification.

\section{Resumo}

Compostos fenólicos são antioxidantes naturais e podem ser encontrados com abundância em frutas e hortaliças. Um dos primeiros métodos criados para análise de compostos fenólicos foi o método Folin-Denis; posteriormente, foi criado o método Folin Ciocalteu e um dos mais recentes é o método Fast Blue. Pela importância desses compostos nos alimentos, este trabalho teve o objetivo principal de determinar os compostos fenólicos totais em três frutas: maracujá, manga e laranja, por três diferentes métodos de determinação. Além disso, foram avaliados o teor de vitamina C, sólidos solúveis, acidez titulável e pH dessas frutas. Diante dos resultados, verificou-se que não houve diferença nos valores de vitamina $C$, sólidos solúveis e acidez titulável em relação aos valores encontrados 
na literatura. Ao comparar os três métodos (Fast Blue BB, Folin Ciocalteu e Folin-Denis), verificou-se diferença nos teores de compostos fenólicos, que pode estar relacionada com os distintos reagentes utilizados em cada método e seus vários modos de ação.

Palavras-chave: Fast Blue BB; Folin-Denis; Folin Ciocalteu; Quantificação.

\section{Introduction}

Phenolic compounds are natural antioxidants sources found in fruits and vegetables. They act as anti-pathogenic agent and contribute to pigmentation, being also responsible for the astringency, aroma and oxidative stability (Angelo \& Jorge, 2007). In human nutrition, phenolic compounds can decrease free radicals present in the body, which may be related to stress, thereby reducing the risk of cardiovascular diseases and others. These compounds are defined as a class of secondary metabolites, which have at least one hydroxyl group attached directly to an aromatic ring (Salvi, 2015).

To quantify total phenolic compounds, there are some methodologies available: Folin-Denis Reagent (FDR), Folin-Ciocalteu Reagent (FCR) and Fast Blue BB. It is interesting to analyze which of these existing methods may be "the best" adjusted to the different needs, taking into consideration which reagents are available as well as their costs. Another interesting factor is whether these three methodologies may be able to estimate values efficiently or even if they present similar results, before replacing one for another, since the methodologies proposed by different researchers have common objectives of evaluating the content of phenolic compounds.

The Folin-Denis method, described by Swain \& Hillis (1959), is based on the reduction of phosphomolybdic-phosphotungstic acid reagents by the phenolic hydroxyls and produces a blue complex that absorbs between 620 and $740 \mathrm{~nm}$, with a maximum wavelength of $760 \mathrm{~nm}$. The reaction occurs in alkaline medium and the saturated solution of sodium carbonate $\left(\mathrm{Na}_{2} \mathrm{CO}_{3}\right)$ tends to be the most indicated base (Angelo \& Jorge, 2007).

The Folin-Ciocalteu method uses the FCR and this reaction is based on the interaction of reducing substances with this FCR (Pires et al., 2017).

Regarding the technique known as "Fast Blue", a coupling reaction takes place between the Fast Blue BB diazonium salt and the phenolic compounds. The reaction occurs in slightly alkaline medium and is quantified by spectrophotometry at $420 \mathrm{~nm}$ (Medina, 2011a). The aim of this work was to quantify the content of Total Phenolic Contents (TPC) from Passion Fruit, "Pera" orange and "Palmer" mango comparing the Folin Denis, Fast Blue BB and Folin-Ciocalteu methods, as well as quantify vitamin C, TA, pH and soluble solids.

\section{Material and methods}

The analyzes were performed at the Post-Harvest Laboratory of the Universidade Federal de Lavras (UFLA), in the state of Minas Gerais (MG). The fruits were obtained in a local market in the city of Lavras (MG) in July 2017.

To prepare the extract, $10 \mathrm{~g}$ of the sample were weighed and $20 \mathrm{~mL}$ of methanol $50 \%$, were homogenized in polytron, centrifuged for 15 minutes at a rotation of $14000 \mathrm{rpm}$ under refrigeration, filtered and stored for further analysis. The extracts were stored in a refrigerator at $8{ }^{\circ} \mathrm{C}$.

The determination of the phenolic compounds by the Folin-Denis method was made according to Deshpande et al. (1986). The analyzes were carried out in triplicate, $0.5 \mathrm{~mL}$ of the sample extract, $8.0 \mathrm{~mL}$ of water, $0.5 \mathrm{~mL}$ of the Folin-Denis solution and $1 \mathrm{~mL}$ of sodium carbonate $\left(\mathrm{Na}_{2} \mathrm{CO}_{3}\right)$ were used. Samples rested for 30 minutes in the dark. The readings were performed through a spectrophotometer at $760 \mathrm{~nm}$ and results were expressed in "mg" of tannic acid/100 g. For performing this analysis, the method of Paula et al. (2016) was followed. 
The determination of phenolic compounds by the Folin-Ciocalteu method was carried out according to Paula et al. (2016). Thus, $0.5 \mathrm{~mL}$ of sample solution, $2.5 \mathrm{~mL}$ of Folin-Ciocalteu, $2.0 \mathrm{~mL}$ of $7.5 \% \mathrm{of}^{\mathrm{Na}_{2} \mathrm{CO}_{3}}$ were added to the tubes. Afterwards, the samples were left resting at room temperature for two hours. Absorbance was read on a spectrophotometer at $760 \mathrm{~nm}$ and the results were expressed in "mg" of gallic acid/100 g. The $\mathrm{pH}$ determination of soluble solids was performed in a digital refractometer according to Association of Analytical Communities (Association of Official Analytical Chemists, 2016), however, soluble solids were expressed in "\%". The TA was determined according to Association of Official Analytical Chemists (2016) and expressed in "\%". Vitamin C was determined according to Strohecker \& Henning (1967) and expressed in "mg" ascorbic acid/100 g. The statistical analysis was performed using the SISVAR software (Ferreira, 2011).

To perform the analysis by Fast Blue BB, this method was adapted from Soares (2015). Thus, $2000 \mathrm{~mL}$ of the fruit sample, $200 \mathrm{~mL}$ of Fast Blue BB reagent was added to test tubes. Subsequently, the tubes were vortexed for three minutes. The samples were kept without light for two hours. Soon after, the samples were vortexed for three minutes and the reading was performed in a spectrometer at $420 \mathrm{~nm}$.

\section{Results and discussion}

Phenolic compounds have important functions for fruits and vegetables, such as cell protection, oxidizing activity and support. They are able to inhibit reactive oxygen species, transfer electrons to free radicals, even as to activate antioxidant enzymes and inhibit oxidase enzymes (Dumitriu et al., 2015).

There was a statistical difference between the values found for TPC by different methods. The highest values were found by Folin-Denis method, whereas the smallest ones by Fast Blue BB (Table 1).

Table 1. Total phenolic average values for "Pera" orange, Passion Fruit and "Palmer" mango measured by Folin-Denis, Folin-Ciocalteu and Fast Blue BB methods.

\begin{tabular}{cccc}
\hline Sample & $\begin{array}{c}\text { Folin-Denis } \\
\text { mg of acid tannic/100 } \mathbf{g}\end{array}$ & $\begin{array}{c}\text { Folin-Ciocalteu } \\
\text { mg of acid gallic/100 g }\end{array}$ & $\begin{array}{c}\text { Fast Blue BB } \\
\text { mg of acid gallic/100 g }\end{array}$ \\
\hline "Pera" orange & $196.00^{\mathrm{a}}$ & $48.83^{\mathrm{b}}$ & $1.84^{\mathrm{c}}$ \\
\hline Passion Fruit & $190.70^{\mathrm{a}}$ & $32.52^{\mathrm{b}}$ & $7.98^{\mathrm{c}}$ \\
\hline "Palmer" mango & $280.27^{\mathrm{a}}$ & $55.04^{\mathrm{b}}$ & $1.83^{\mathrm{c}}$ \\
\hline
\end{tabular}

Averages followed by the same letters do not differ from each other by the Tukey's test, at 5\% significance.

It is assumed that this difference is due to the reagents used in each method and the interference of these reagents in the phenolic compounds present in the fruits.

The Folin-Denis method is not a specific method, since it determines all phenolic compounds, in addition reducing substances, these compounds may interfere in the results (Angelo \& Jorge, 2007). The Folin-Ciocalteu method is a more sensitive method to reduce phenolic compounds and decrease the tendency of precipitation (Angelo \& Jorge, 2007). The Fast Blue BB method consists on the "elimination" of possible interference of non-phenolic compounds, as well as found in the Folin-Ciocalteu methodology (Medina, 2011b).

Other authors compared some of these methods and had similar results. Chaves (2014) evaluated the efficiency of two techniques, such as Folin-Ciocalteu and Fast Blue, in strawberry cultivars. The techniques are the same when the levels of phenolic compounds are observed (Chaves, 2014).

In another work regarding TPC, the authors compared two methods (Folin-Ciocalteu and Folin-Denis) in barks of Angico-vermelho and could find that the methodologies used in the quantification of TPC were statistically the same (Sartori et al., 2014). In addition, they indicated the use of the Folin-Denis methodology, because they spent less reagents and it resulted in lower costs and generation of chemical residues (Sartori et al., 2014). 
Finally, Lester et al. (2012) studied test interference comparing Folin-Ciocalteu and Fast Blue BB methods in strawberries and the results showed that the Fast Blue BB assay provided more accurate estimates of TPC due to the direct reaction with phenolic compounds present in strawberry (Lester et al., 2012).

According to the knowledge of the $\mathrm{pH}$ values, it is possible to produce foods with significant acceptance by consumers, seeing that each product has an ideal $\mathrm{pH}$ range, however, this also interferes in the food shelf life. Food with lower $\mathrm{pH}$ may have greater resistance to micro-organism attacks. "Palmer" mango is the fruit with the lowest acidity, among the fruits analyzed (Table 2).

Table 2. Average pH values of "Palmer" mango, "Pera" orange and Passion Fruit.

\begin{tabular}{cc}
\hline Sample & pH \\
\hline "Palmer" mango & $5.01^{\mathrm{a}}$ \\
\hline "Pera" orange & $3.74^{\mathrm{b}}$ \\
\hline Passion Fruit & $3.11^{\mathrm{c}}$ \\
\hline
\end{tabular}

Averages followed by the same letters do not differ from each other by the Tukey's test, at $5 \%$ significance.

The results obtained in this work are similar to those found by other authors when evaluating the same fruits. In the yellow Passion Fruit pulp, pH values ranged between 3.03 and 3.51 (Gomes et al., 2009). For the "Tommy Atkins" mango, it could be obtained a pH result between 4.04 and 4.38 (Brunini et al., 2002). A study with varieties of oranges showed that the $\mathrm{pH}$ from these oranges ranged from 3.11 to 4.04 (Venâncio \& Martins, 2012).

Organic acids present in foods have important functions in terms of taste, odor, color, stability, quality maintenance and shelf life (Souza et al., 2010). In view of the results, the TA value of the "Palmer" mango was the lowest, by indicating the lowest acidity (Table 3).

Table 3. The average values of titratable acidity (TA) of "Palmer" mango, "Pera" orange and Passion Fruit.

\begin{tabular}{cc}
\hline Sample & Titratable acidity (\%) \\
\hline "Palmer" mango & $0.13^{\mathrm{c}}$ \\
\hline "Pera" orange & $0.83^{\mathrm{b}}$ \\
\hline Passion Fruit & $4.43^{\mathrm{a}}$ \\
\hline
\end{tabular}

Averages followed by the same letters do not differ from each other by the Tukey's test, at $5 \%$ significance.

In the study performed by Couto \& Canniatti-Brazaca (2010), the TA of orange and tangerine ranged between 0.23 and 1.48, and these values were expressed in percentage of citric acid to $100 \mathrm{~mL}$ of juice. The value of TA (\%) in "Pera" oranges ranged between 1.14\% and 0.12\% (Lim et al., 2007). For Passion Fruit, the Total Titratable Acidity (TTA) in a work that evaluated the characteristics of this fruit ranged between $3.9 \%$ and $4.4 \%$ (Cavichioli et al., 2011). In a study of characterization of mango tree fruits, the TA for "Palmer" mango was $0.20 \%$ (Silva et al., 2009).

With the ripening of the fruits, the soluble solids may increase due to the degradation of stock substances such as glucose, fructose, sucrose and starch (Payasi et al., 2009). Orange was the fruit that presented the lowest soluble solids content and it might be a characteristic of a fruit that has less sugar than the other fruits evaluated (Table 4).

Table 4. Soluble solids average values of "Palmer" mango, "Pera" orange and Passion Fruit.

\begin{tabular}{cc}
\hline Sample & Soluble solids (\%) \\
\hline "Palmer" mango & $13.15^{\mathrm{b}}$ \\
\hline "Pera" orange & $8.65^{\mathrm{c}}$ \\
\hline Passion Fruit & $15.65^{\mathrm{a}}$ \\
\hline
\end{tabular}

Averages followed by the same letters do not differ from each other by the Tukey’s test, at $5 \%$ significance. 
The values of soluble solids can vary according to maturation, planting site and time of the year. Couto \& Canniatti-Brazaca (2010) could evaluate soluble solids values in oranges and tangerines, and the soluble solids values were 9.11 and $14.33 \%$, respectively. Comparing to tropical fruits, a value of 10.60 and $0.09^{\circ}$ Brix was obtained in "Pera" orange. The soluble solids content for mango could range from 10 to 13\% (Medlicott et al., 1988). For Passion Fruit juice, the value of soluble solids was from 11 to $20 \%$ (Pinheiro et al., 2006).

The main sources of vitamin $\mathrm{C}$ (ascorbic acid) are fruits and vegetables, and the ascorbic acid content of fruits and vegetables may decrease during storage owing to oxidation that is dependent on factors such as light, temperature and the presence of oxidizing enzymes (Cheftel, 1992). In this work, the values of vitamin C found in "Palmer" mango, "Pera" orange and Passion Fruit are shown in Table 5. According to these results, it was possible to verify that "Palmer" mango was the fruit that presented higher content of vitamin C.

Table 5. The average values of vitamin C for "Palmer" mango, "Pera" orange and Passion Fruit.

\begin{tabular}{cc}
\hline Sample & Vitamin C (mg of ascorbic acid/100 g) \\
\hline "Palmer" mango & $82.15^{\mathrm{a}}$ \\
\hline "Pera" orange & $37.30^{\mathrm{c}}$ \\
\hline Passion Fruit & $42.17^{\mathrm{b}}$ \\
\hline
\end{tabular}

Averages followed by the same letters do not differ from each other by the Tukey's test, at $5 \%$ significance.

Regarding the vitamin C of Passion Fruit, the authors De Marchi et al. (2000) obtained a variation from approximately 11.53 to $27.02 \mathrm{mg}$ of ascorbic acid/100 g, when the vitamin C content in yellow Passion Fruit in four different harvests were evaluated, nevertheless, these values were below to those found in this work. The ascorbic acid content in Passion Fruit was approximately from 30 to $40 \mathrm{mg} / 100 \mathrm{~g}$ of each sample (Vasco et al., 2008).

Regarding the quantification of vitamin $\mathrm{C}$ and antioxidant capacity of citrus varieties, a value of approximately $62.50 \mathrm{mg}$ of ascorbic acid/100 mL was verified for "Pera" orange (Couto \& Canniatti-Brazaca, 2010), which is a higher value than those verified in this study. Vitamin C values may vary according to fruit variety, maturation degree and place of production (Couto \& Canniatti-Brazaca, 2010). These results may justify the differences found between the studies conducted over the past years.

\section{Conclusion}

According to the results obtained with the present work, the values of $\mathrm{pH}$, soluble solids and TA are in accordance with the literature, showing there was no significant variation among the averages found by other researchers. When comparing the Folin-Denis, Folin-Ciocalteu and Fast Blue BB methodologies accompanied by using three varieties of fruits ("Palmer" mango, Passion Fruit and "Pera" orange), the values of the phenolic compound contents were different, indicating that there was a difference between the three methods regarding the phenolic compounds present in the fruits.

Probably, the differences detected in the phenolic compounds values between the methodologies may be related to the reagents performance by the interaction with the phenolic compounds in the fruits.

\section{Acknowledgements}

The authors are grateful to the Coordenação de Aperfeiçoamento de Pessoal de Nivel Superior - Brazil (CAPES) - Financing Code 001 by supporting the scholarship.

\section{References}

Angelo, P. M., \& Jorge, N. (2007). Compostos fenólicos em alimentos-uma breve revisão. Revista do Instituto Adolfo Lutz, $66(1), 1-9$. 
Association of Official Analytical Chemists - AOAC. (2016). Official methods of analysis of the Association of the Agricultural Chemists. Washington:AOAC.

Brunini, M. A., Durigan, J. F., \& Oliveira, A. L. (2002). Avaliação das alterações em polpa de manga 'tommy-atkins' congeladas. Revista Brasileira de Fruticultura, 24(3), 651-653. http://dx.doi.org/10.1590/S0100-29452002000300019

Cavichioli, J. C., Corrêa, L. D. S., Boliani, A. C., \& Santos, P. C. D. (2011). Características físicas e químicas de frutos de maracujazeiro-amarelo enxertado em três porta-enxertos. Revista Brasileira de Fruticultura, 33(3), 906-914. http://dx.doi.org/10.1590/S0100-29452011000300026

Chaves, V. C. (2014). Teor de antocianinas, compostos fenólicos e capacidade de captação de radicais livres de frutos de cultivares de morangueiro (Fragaria $x$ ananassa Duch) (Tese de doutorado). Universidade Federal de Santa Catarina, Florianópolis.

Cheftel, J.-C. (1992). Effects of high hydrostatic pressure on food constituents (pp. 195). London: Institut National de la Santé et de la Recherche Médicale.

Couto, M. A. L., \& Canniatti-Brazaca, S. G. (2010). Quantificação de vitamina c e capacidade antioxidante de variedades cítricas. Food Science and Technology, 30(1), 15-19. http://dx.doi.org/10.1590/S0101-20612010000500003

De Marchi, R., Monteiro, M., Benato, E. A., \& Silva, C. A. R. (2000). Uso da cor da casca como indicador de qualidade do maracujá amarelo (Passiflora edulis Sims. f. flavicarpa Deg.) destinado à industrialização. Food Science and Technology, 20(3), 381-387. http://dx.doi.org/10.1590/S0101-20612000000300017

Deshpande, S. S., Cheryan, M., Salunkhe, D. K., \& Luh, B. S. (1986). Tannin analysis of food products. Critical Reviews in Food Science and Nutrition, 24(4), 401-449. PMid:3536314. http://dx.doi.org/10.1080/10408398609527441

Dumitriu, D., Peinado, R. A., Peinado, J., \& De Lerma, N. L. (2015). Grape pomace extract improves the in vitro and in vivo antioxidant properties of wines from sun light dried pedro ximénez grapes. Journal of Functional Foods, 17, 380-387. http://dx.doi.org/10.1016/j.jff.2015.06.003

Ferreira, D. F. (2011). Sisvar: A computer statistical analysis system. Ciência e Agrotecnologia, 35(6), 1039-1042. http://dx.doi.org/10.1590/S1413-70542011000600001

Gomes, T. S., Chiba, H. T., Simionato, E. M. R. S., \& Sampaio, A. C. (2009). Qualidade da polpa de maracujá amarelo-seleção afruvec, em função das condições de armazenamento dos frutos. Alimentos e Nutrição, 17(4), 401-405.

Lester, G. E., Lewers, K. S., Medina, M. B., \& Saftner, R. A. (2012). Comparative analysis of strawberry total phenolics via fast blue bb vs. folin-ciocalteu: Assay interference by ascorbic acid. Journal of Food Composition and Analysis, 27(1), $102-107$. http://dx.doi.org/10.1016/j.jfca.2012.05.003

Lim, Y., Lim, T., \& Tee, J. (2007). Antioxidant properties of several tropical fruits: A comparative study. Food Chemistry, 103(3), 1003-1008. http://dx.doi.org/10.1016/j.foodchem.2006.08.038

Medina, M. B. (2011a). Determination of the total phenolics in juices and superfruits by a novel chemical method. Journal of Functional Foods, 3(2), 79-87. http://dx.doi.org/10.1016/j.jff.2011.02.007

Medina, M. B. (2011b). Simple and rapid method for the analysis of phenolic compounds in beverages and grains. Journal of Agricultural and Food Chemistry, 59(5), 1565-1571. PMid:21309564. http://dx.doi.org/10.1021/jf103711c

Medlicott, A. P., Reynolds, S. B., New, S. W., \& Thompson, A. K. (1988). Harvest maturity effects on mango fruit ripening. Tropical Agriculturist, 65, 153-157.

Paula, M. M. O., Mendes, N. S., Arantes, M. B. S., Gloria, L. L., Pereira, S. M. F., \& Oliveira, D. B. (2016). Quantificação do teor de fenólicos totais de aroeira (Schinus terebinthifolius Raddi) através de duas metodologias distintas. In XXV Congresso Brasileiro de Ciência e Tecnologia de Alimentos. Alimentação: A árvore que sustenta a vida. Gramado: FAURGS.

Payasi, A., Mishra, N. N., Chaves, A. L., \& Singh, R. (2009). Biochemistry of fruit softening: An overview. Physiology and Molecular Biology of Plants, 15(2), 103-113. PMid:23572919. http://dx.doi.org/10.1007/s12298-009-0012-z

Pinheiro, A. M., Fernandes, A. G., Fai, A. E. C., Prado, G. D., Sousa, P. D., \& Maia, G. A. (2006). Avaliação química, físicoquímica e microbiológica de sucos de frutas integrais: Abacaxi, caju e maracujá. Food Science and Technology, 26(1), 98-103. http://dx.doi.org/10.1590/S0101-20612006000100017

Pires, J., Torres, P. B., Santos, D. Y. A. C., \& Chow, F. (2017). Ensaio em microplaca de substâncias redutoras pelo método do Folin-Ciocalteu para extratos de algas. São Paulo: Instituto de Biociências, Universidade de São Paulo.

Salvi, A. D. O. (2015). Caracterização fitoquímica e avaliação do potencial antioxidante e antimicrobiano de capsicum chinense jacquin (pimenta bode-roxo) (Dissertação de mestrado). Universidade Federal de Santa Catarina, Florianópolis.

Sartori, C. J., Castro, A. H. F., \& Mori, F. A. (2014). Teores de fenóis totais e taninos nas cascas de angico-vermelho (Anadenanthera peregrina). Floresta e Ambiente, 21(3), 394-400. http://dx.doi.org/10.1590/2179-8087.061113

Silva, D. F., Siqueira, D. L., Pereira, C. S., Salomão, L. C. C., \& Struiving, T. B. (2009). Caracterização de frutos de 15 cultivares de mangueira na zona da mata mineira. Revista Ceres, 56(6), 783-789.

Soares, C. A. (2015). Validação do método fast blue para quantificação de compostos fenólicos totais em alimentos (Trabalho de conclusão de graduação). Universidade Federal do Rio Grande do Sul, Porto Alegre.

Souza, L. M., Correia, K. C., Santos, A. D., Barreto, L. P., \& Bezerra Neto, E. (2010). Comparação de metodologias de análise de ph e acidez titulável em polpa de melão. In X Jornada de Ensino, Pesquisa e Extensão. Recife: UFRPE.

Strohecker, R., \& Henning, H. M. (1967). Análisis de vitaminas, métodos comprobados. Madrid: Paz Montalvo.

Swain, T., \& Hillis, W. (1959). The phenolic constituents of prunus domestica: The quantitative analysis of phenolic constituents Journal of the Science of Food and Agriculture, 10(1), 63-68. http://dx.doi.org/10.1002/jsfa.2740100110 
Evaluation of different methodologies for the determination of phenolic compounds in tropical fruits

Guimarães, K. C. et al.

Vasco, C., Ruales, J., \& Kamal-Eldin, A. (2008). Total phenolic compounds and antioxidant capacities of major fruits from Ecuador. Food Chemistry, 111(4), 816-823. http://dx.doi.org/10.1016/j.foodchem.2008.04.054

Venâncio, A. A., \& Martins, O. A. (2012). Análise química de diferentes marcas de néctares e suco de laranja comercializada na cidade de Cerqueira César - São Paulo. Revista Eletrônica de Educação e Ciência, 2(3), 45-50.

Funding: Coordenação de Aperfeiçoamento de Pessoal de Nível Superior - Brazil (CAPES) - Financing Code 001 by grant of scholarship. 